\title{
Founding of the French Zoosemiotics Society
}

\author{
Pauline Delahaye $^{1}$
}

As the country of René Descartes, France used to keep humanities, especially linguistics, far away from biology in general, and from animals in particular. Semiotics theories and tools, mainly those of Algirdas Julien Greimas and Ferdinand de Saussure, are mostly used for textual studies, and talking about "animal language" in the venerable Sorbonne is a very delicate subject.

To propose another academic way of using semiotics in animal studies, Astrid Guillaume $^{2}$ (Sorbonne Université) and Carlos Pereira ${ }^{3}$ (Sorbonne Nouvelle) founded the French Zoosemiotics Society (Société Française de Zoosémiotique) ${ }^{4}$. Until now, the semiotics field in France only seldom included animals as an object of study - except in studies or theses supervised by Astrid Guillaume, Carlos Pereira, and a few other scholars - and there was no real institution, doctoral school or university unit where to work on zoosemiotics. The main purpose was to create a scientific structure which can play this part, promote the field, and support the researchers' enterprise of implementing the discipline in their own work.

Uniting linguists (François Rastier), semioticians, ethologists (Georges Chapouthier, Sabrina Krief, Michel Kreutzer), veterinarians and philosophers, the society wishes to promote a semiotic approach in animal studies. At the moment, almost all works in French zoosemiotics are published either in non-French journals ${ }^{5}$ or by private foundations ${ }^{6}$ which can be run by scientists, but do not belong to the strictly academic world. By bringing together scientists of various

1 EA 4509 - Sens, Texte, Informatique, Histoire; Sorbonne University, Paris, France; e-mail: delahayepauline@gmail.com.

2 Semiotician and a member of the LFDA (Animal Rights, Ethics and Sciences Foundation). See Guillaume 2013a; 2013b; 2014.

3 Semiotician, horseman and Associated Researcher at Kyoto University for equines' cognition and wild Garranos pony behaviour study programmes. See Pereira 2009; 2016; Ringhofer et al. 2017.

4 See the Society's website at http://societefrancaisedezoosemiotique.fr/.

5 For instance, Guillaume 2013a.

6 For instance, Delahaye 2017. 
nationalities and academic traditions - of course, France, but also Belgium, Portugal or Japan - the Society expects to counter the ancient French prejudice against animal studies - concerning animal language, culture, emotions, consciousness etc. - being part of the humanities field, and denigration of research on these subjects.

Although the Society was founded only recently, it has already participated in organizing seminars ${ }^{7}$, colloquiums ${ }^{8}$ and launched its own book series, Collection Zoosémiotique, for the publication of works on zoosemiotics in French with the publishing house L'Harmattan, which reviews, supports and implements zoosemiotics-centred book projects. This year, the Society will organize monthly seminars on various zoosemiotics subjects or interdisciplinary subjects bringing together semiotics and animals ${ }^{9}$. Its purpose is now to work increasingly more with international partners, to expand the semiotic approach in life and animal studies, and to defend the Animal as a real, worthy, scientific research object.

\section{References}

Delahaye, Pauline 2017. Des signes pour le dire. Revue trimestrielle de la Fondation Droit Animal, Ethique et Sciences 97: 36.

Guillaume, Astrid 2013a. Humanity and animality: A transdisciplinary approach. Human and Social Studies 2(3): 13-30.

- 2013b. Question de définitions. Humanité versus Animalité? Sémiotique de l’animal. Revue trimestrielle de la Fondation Droit Animal, Ethique et Sciences 79: 22-24.

- 2014. Animal: "être sensible" unanimement désensibilisé. Sémiotique du sensible. Revue trimestrielle de la Fondation Droit Animal, Ethique et Sciences 81: 35-37.

Pereira, Carlos 2009. Parler aux chevaux autrement: Approche sémiotique de léquitation. Paris: Amphora.

- 2016. Equitation classique: Le langage des aides. Paris: Vigot.

Ringhofer, Monamie; Inoue, Sota; Mendonça, Renata S.; Pereira, Carlos; Matsuzawa, Tetsuro; Hirata, Satoshi; Yamamoto, Shinya 2017. Comparison of the social systems of primates and feral horses: Data from a newly established horse research site on Serra D’Arga, northern Portugal. Primates 58(4): 479-484.

7 March 2018 - "Mathematics and zoosemiotics: New theoretical paradigms for interspecies translation". Hosted by Paris-Sorbonne University, with speakers Olivia Caramello (Insubrie University, Italy) and Charles Alunni (ENS, France).

8 December 2018 - "250 Years of Circus". Hosted by Sorbonne University, with semioticians, ethologists and circus artists (the Bouglione family).

9 The first session, entitled "Terminology, neology and zoosemiotics", is scheduled for 29 September 2018. Hosted by Sorbonne University, with the participation of the STIH (Sens, Texte, Informatique, Histoire) Sorbonne Research Unit and the European Observatory of Plurilingualism. 